\title{
KARAKTERISTIK INSTANT NOODLE DARI PATI JAGUNG TERMODIFIKASI
}

\author{
Instant Noodle Characteristics of Modification of Maize Corn \\ Lamria Mangunsong ${ }^{1)}$ \\ 1) Jurusan Teknologi Pertanian, Politeknik Negeri Pontianak, \\ email : lamriasanopti@yahoo.com
}

\begin{abstract}
Natural corn starch (native) has a weakness as an instant noodle material. With the treatment modification of Autoclaving-Cooling and Heat Moisture Treatment (AC-HMT) is expected to use corn starch to produce better Instant Noodle. The purpose of this study was to evaluate the physical characteristics of Instant Noodle corn from the formulation of corn starch and modified corn starch. The method of this research consists of three stages, the first step is corn starch extraction. The second step is Corn starch modification with AC-HMT combination method which is corn susceptibility of $20 \% \mathrm{w} / \mathrm{w}$ formed at $700 \mathrm{C}$ temperature heated by autoclave for 15 minutes, at 1200C, followed by HMT process with HMT treatment 15 minutes (autoclave for 15 minutes). While the third stage is the manufacture of Instant Noodle. The experimental design used in this study is the Complete Factorial Design that is the ratio between corn starch and starch modification of the best treatment of corn starch modification is then used for its application in the manufacture of instant noodle with the ratio between cornstarch and modified corn starch is divided into five formulas that is 100: 0; 75:25; 50:50; 25:75; 0: 100. The results of this study indicate that the formula instant noodle maize 25:75 produces better characteristics with water content, tensile strength, elongation, solubility and swelling power as follows 9,8466\%, $0.4767 \mathrm{~N}, 68.4738 \%, 1.1869 \%$, and $39.6540 \%$
\end{abstract}

Keywords: Corn starch, instant noodle, Autoclaving-Cooling and Heat Moisture Treatment (AC-HMT), elongation, tensile strenght

\begin{abstract}
ABSTRAK
Pati jagung alami (native) memiliki kelemahan sebagai bahan instant noodle. Dengan perlakuan modifikasi Autoclaving-Cooling dan Heat Moisture Treatment (AC-HMT) diharapkan penggunaan pati jagung dapat menghasilkan Instant Noodle yang lebih baik. Adapun tujuan dari penelitian ini adalah mengevaluasi karakteristik fisik Instant Noodle jagung hasil formulasi dari tepung jagung dan pati jagung modifikasi. Metode penelitian ini terdiri dari tiga tahapan, tahap pertama adalah ekstrasi pati jagung Tahap kedua adalah Modifikasi pati jagung dengan metode kombinasi AC-HMT yaitu susupensi pati jagung $20 \% \mathrm{~b} / \mathrm{b}$ yang terbentuk pada suhu $70^{\circ} \mathrm{C}$ dipanaskan dengan autoklaf selama 15 menit, pada suhu $120^{\circ} \mathrm{C}$, dilanjutkan dengan proses HMT dengan perlakuan HMT 15 menit (autoklaf selama 15 menit). Sedangkan tahap ketiga adalah pembuatan Instant Noodle. Rancangan percobaan yang digunakan dalam penelitian ini adalah RancanganAcak Lengkap factorial yaitu perbandingan antara tepung jagung dan pati modifikasi perlakuan yang terbaik dari modifikasi pati jagung selanjutnya digunakan untuk aplikasinya pada pembuatan instant Noodle dengan perbandingan antara tepung jagung dan pati jagung termodifikasi dibedakan menjadi lima formula yaitu 100: $0 ; \quad 75: 25 ; 50: 50 ; 25: 75 ; 0: 100$. Hasil penelitian ini menunjukkan bahwa formula instant noodle jagung 25:75 menghasilkan karakteristik yang lebih baik dengan kadar air, tensile strength, elongasi, kelarutan dan swelling power sebagai berikut 9,8466\%, 0,4767N, 68,4738\%, $1,1869 \%$, dan $39,6540 \%$
\end{abstract}

Kata Kunci: Pati jagung, Instant Noodle, Autoclaving-Cooling dan Heat Moisture Treatment(AC-HMT), elongasi, tensile strenght 


\section{PENDAHULUAN}

Jagung (Zea mays) merupakan salah satu serealia yang strategis dan bernilai ekonomis serta mempunyai peluang untuk dikembangkan karena kedudukannya sebagai sumber utama karbohidrat dan protein setelah beras. Berdasarkan komposisi kimia dan kandungan zat gizinya, jagung mempunyai prospek sebagai bahan pangan dan bahan baku industri. Saat ini masyarakat sudah banyak mengkonsumsi instant noodle sebagai salah satu makanan kaya karbohidrat mengandung sumber kalori tinggi.

Instant noodle umumnya terbuat dari tepung terigu yang masih harus diimpor dari luar negeri. Pemilihan jagung sebagai bahan baku alternatif dalam pembuatan Instant Noodle sesuai dengan Peraturan Presiden Nomor 22 Tahun 2009 tentang Kebijakan Percepatan Penganeka ragaman Konsumsi Pangan Berbasis Sumber daya Lokal. Pembuatan instant noodle jagung telah banyak dilakukan tetapi masih memiliki kelemahan yaitu karakter fisik yang keras, kurang elastis, lebih lengket dan memiliki prosentase kehilangan padatan akibat pemasakan yang tinggi dibanding Instant Noodle dari tepung gandum. Salah satu alternatif dengan melakukan modifikasi pati jagung. Proses modifikasi mengubah struktur dan mempengaruhi ikatan hidrogen molekul pati secara terkontrol. Hal ini dilakukan untuk memperbaiki karakteristik fisiko-kimia pati agar sesuai untuk suatu aplikasi spesifik. Perubahan di tingkat molekuler ini tidak atau hanya sedikit mengubah bentuk granula pati, sehingga asal botani pati termodifikasi masih bisa dikenali secara mikroskopik.

Modifikasi pati dapat dilakukan dengan berbagai cara seperti: secara kimia, biokimia, dan fisik (Syamsir dkk., 2012). Salah satu alternatif dengan melakukan modifikasi pati jagung secara fisik dengan metode Autoclaving-Cooling yang bersifat relatif aman dan sederhana untuk dilakukan dan dapat memperbaiki sifat fisik, kimia dan fungsional dari pati alami. Selanjutnya pembuatan instant Noodle dengan pengembangan formulasi tepung dan pati jagung. $n$

Formulasi instant noodle jagung telah dikembangkan dalam beberapa penelitian, diantaranya Juniawati (2003) telah membuat instant noodle jagung dengan bahan dasar tepung jagung. Budiyah (2004) melakukan pembuatan instant noodle jagung dengan memanfaatkan pati jagung dan protein jagung (Corn Gluten Meal). Fadlillah (2005) melakukan verifikasi pada desain proses produksi dan formulasi instant noodle jagung metode budidaya dengan menambahkan protein gluten terigu untuk memperbaiki elastisitas dan cooking loss noodle.

Penelitian ini bertujuan mengetahui karakteristik fisik Instant Noodle pati jagung yang telah mengalami modifikasi fisik Autoclaving Cooling-Heat Moisture Treatment dengan pengembangan formulasi tepung jagung dan pati jagung termodifikasi.

\section{BAHAN DAN METODE}

\section{Bahan}

Bahan digunakan pada penelitian ini adalah jagung varietas lokal, plastik polietilen, telur, baking powder, CMC, aguades, karet gelang.

\section{Alat}

Alat utama yang digunakan dalam penelitian ini adalah Autoclave, timbangan, pengaduk mekanik atau manual, gunting, desikator, baskom, blender, oven, Lioyd Instrument, teksture analyzer, loyang, serta alat-alat glassware.

\section{Metode}

Penelitian ini terdiri dari tiga tahapan, tahap pertama adalah mengekstraksi pati jagung lokal, Tahap kedua modifikasi pati dengan metode kombinasi AutoclavingCooling dan HMT (AC-HMT) sedangkan tahap ketiga adalah pembuatan instant noodle . 
Tahap Pertama: adalah mengekstraksi pati jagung lokal dengan metode Collado dan Corke (2001). Pati jagung diekstraksi dengan tahapan sebagai berikut: jagung lokal di hancurkan dengan blender. Kemudian diekstraksi dengan perbandingan air dan bahan 1:1 dan dilakukan penyaringan dengan menggunakan saringan ukuran 200 mesh hingga diperoleh filtrat 1). Ampas yang diperoleh, kemudian dicampurkan lagi dengan air dengan perbandingan air dan ampas 1:0,5 dan dilakukan penyaringan hingga diperoleh filtrat 2). Filtrat 1 dan 2 dicampur, kemudian dilakukan pengendapan selama 6 jam, dan setiap 3 jam dilakukan penggantian air. Air dan endapan kemudian dipisah dan endapan yang diperoleh disebut pati basah. Pati basah kemudian dikeringkan dengan menggunakan oven pengering selama 1 malam pada suhu $50^{\circ} \mathrm{C}$, hingga diperoleh pati kering. Pati kering selanjutnya digiling dan diayak dengan menggunakan ayakan ukuran 200 mesh, dan diperolehlah pati dalam bentuk tepung. Pati yang diperoleh disimpan dalam wadah yang tertutup rapat.

Tahap kedua : Tahap kedua modifikasi pati dengan metode kombinasi AutoclavingCooling dan HMT (Zakiyah, 2005; Anand, 2015).

Tahap awal sebelum modifikasi pati Autoclaving-Cooling, dilakukan pemanasan awal pati jagung $20 \% \mathrm{~b} / \mathrm{b}$ pada suhu $70^{\circ} \mathrm{C}$, disertai dengan pengadukan sampai terbentuk suspensi yang homogen ditandai dengan peningkatan viskositas. Selanjutnya pati dipanaskan dengan autoklaf selama 15 menit, pada suhu $120^{\circ} \mathrm{C}$. Setelah itu didinginkan selama 1 jam pada suhu ruang, lalu diretrogradasi melalui pendinginan selama 24 jam pada suhu $4{ }^{0} \mathrm{C}$. Pati kemudian dikeringkan menggunakan oven (suhu $60^{\circ} \mathrm{C}$ ) selama 16 jam dan dihaluskan serta diayak dengan ayakan 80 mesh. Pati hasil modifikasi Autoclaving-Cooling (AC) dilanjutkan dengan proses HMT dengan perlakuan HMT 15 menit (autoklaf selama 15 menit). Proses HMT dilakukan dengan tahapan sebagai berikut: Sebanyak $200 \mathrm{~g}$ pati Jagung termodifikasi AC diatur kadar airnya hingga mencapai $20 \%$ dengan menyemprotkan aquades. Pati basah yang telah mencapai kadar air $20 \%$ bb selanjutnya diaduk dan ditempatkan di dalam plastik HDPE bertutup disimpan (conditioning) di dalam lemari es (suhu $5^{0} \mathrm{C}$, selama 12 jam) agar penyebaran air pada tepung merata. Selanjutnya Pati basah diberikan perlakuan HMT dengan cara dipanaskan dalam Autoklaf pada suhu $120^{\circ}$ Cselama 15 menit (AC-HMT15') dan 30 menit (AC-HMT60') untuk memperoleh pati modifikasi. Selanjutnya, sampel pati dari perlakuan tersebut dikeringkan dengan cabinet drier selama 2 jam pada suhu $50^{\circ}$ C. Sampel yang sudah kering digiling dan diayak 80 mesh serta dikemas dalam kantung plastik.

Tahap ketiga: Pembuatan Instant Noodle

Tahapan pembuatan instant Noodle terdiri dari tahap pencampuran, pembentukan lembaran, pembentukan mie, pengukusan, penggorengan, pendinginan serta pengemasan. Pembuatan instant noodle dilakukan dengan perbandingan antara tepung jagung dan pati jagung termodifikasi dibedakan menjadi lima formula yaitu 100: $0 ; \quad 75: 25 ; \quad 50: 50 ; 25: 75 ; \quad 0: 100$. Tahap pencampuran meliputi perbandingan tepung jagung: pati jagung, pencampuran telur dan air 1:1 sebanyak $150 \mathrm{ml}, \mathrm{CMC} 7,5 \%$, baking powder $5 \%$, garam $5 \%$ diaduk sampai adonan kalis. Proses pembentukan lembaran pada alat Amphia bertujuan untuk menghaluskan serat-serat gluten dan membuat lembaran adonan. Setelah pembentukan noodle dilakukan proses pengukusan. Selanjutnya dilakukan pengeringan dengan cabinet drier pada suhu $70^{\circ} \mathrm{C}$ selama 4 jam. Pati didinginkan sebelum dilakukan pengemasan.

\section{Rancangan Penelitian}

Rancangan percobaan yang digunakan dalam penelitian ini adalah RAL (Rancangan Acak Lengkap) factorial yaitu perbandingan antara tepung jagung dan pati jagung termodifikasi dibedakan menjadi lima formula yaitu 100: $0 ; 75: 25$; 
50:50; 25:75; 0:100. Masing-masing perlakuan diulang 3 (tiga) kali, sehingga menghasilkan sebanyak 15 kombinasi perlakuan.

\section{Analisa Data}

Data yang diperoleh dalam penelitian ini akan dianalisa menggunakan Analysis of Variance (ANAVA). Jika ternyata terdapat perbedaan maka perlu dilakukan uji statistika lanjut dengan menggunakan uji Duncan's Multiple Rang Test. Analisa statistic seluruhnya diolah menggunakan program software SPSS.

\section{HASIL DAN PEMBAHASAN}

Pati jagung alami memiliki kadar amilosa yang rendah, sehingga untuk pengembangan penggunaannya dalam produk pangan, pati jagung harus dilakukan modifikasi yaitu modifikasi secara fisik yang bersifat aman, sederhana dan mudah penggunaannya yaitu AC-HMT. Adapun hasil analisa pati jagung hasil modifikasi dapat dilihat pada Tabel 1 dibawah ini.

Dari tabel 1 terlihat bahwa pati jagung mengalami peningkatan kadar amilosanya setelah dilakukan modifikasi sehingga mengubah struktur dan mempengaruhi ikatan hidrogen molekul pati menjadi lebih kompak dan kuat.

Pati hasil modifikasi AC_HMT digunakan sebagai bahan Formulasi pembuatan instant noodle yaitu perbandingan antar tepung jagung dan pati jagung modifikasi yaitu 100:0; 75:25; 50:50; 25:75; 0:100, dengan karakteristik fisik Instant Noodle yang diamati meliputi kadar air, tensile strength, elongasi, kelarutan dan swelling power dan hasil analisa fisiknya dapat dilihat pada Tabel 2 dibawah ini.

Tabel 1. Hasil analisa pati jagung alami dan pati modifikasi

\begin{tabular}{lcc}
\multicolumn{1}{c}{ Sampel } & Kadar air (\%) & Kadar amilosa (\%) \\
\hline Pati alami & 7.555 & 18.794 \\
Pati jagung hasil modifikasi & 9,948 & 29.528 \\
AC-HMT & & \\
\hline
\end{tabular}

Tabel 2. Data analisa kadar air, tensile strength, elongasi dan kelarutan pati AC_HMT pada formulasi Noodle

\begin{tabular}{cccccc}
\hline Sampel & $\begin{array}{c}\text { Kadar Air } \\
(\%)\end{array}$ & $\begin{array}{c}\text { Tensile } \\
\text { Strenght } \\
(\mathrm{N})\end{array}$ & $\begin{array}{c}\text { Elongasi } \\
(\%)\end{array}$ & $\begin{array}{c}\text { Kelarutan } \\
(\%)\end{array}$ & $\begin{array}{c}\text { Swelling power } \\
(\%)\end{array}$ \\
\hline IN-A & $9,8512^{\mathrm{a}}$ & $0,0403^{\mathrm{f}}$ & $15,3938^{\mathrm{e}}$ & $5,3026^{\mathrm{a}}$ & $20,4701^{\mathrm{d}}$ \\
IN-B & $9,8490^{\mathrm{a}}$ & $0,1972^{\mathrm{d}}$ & $30,8451^{\mathrm{d}}$ & $4,8540^{\mathrm{b}}$ & $25,5644^{\mathrm{c}}$ \\
IN-C & $9,8449^{\mathrm{a}}$ & $0,3770^{\mathrm{c}}$ & $53,0242^{\mathrm{c}}$ & $3,2250^{\mathrm{c}}$ & $28,0366^{\mathrm{b}}$ \\
IN-D & $9,8466^{\mathrm{a}}$ & $\mathbf{0 , 4 7 6 7}^{\mathrm{a}}$ & $\mathbf{6 8 , 4 7 3 5}^{\mathrm{a}}$ & $1,1869^{\mathrm{d}}$ & $39,6540^{\mathrm{a}}$ \\
IN-E & $9,8523^{\mathrm{a}}$ & $0,4439^{\mathrm{ab}}$ & $66,7147^{\mathrm{b}}$ & $1,2005^{\mathrm{d}}$ & $39,6508^{\mathrm{a}}$ \\
IN-F & $9,8454^{\mathrm{a}}$ & $0,0974^{\mathrm{e}}$ & $17,4739^{\text {ef }}$ & $2,9988^{\mathrm{cd}}$ & $29,3211^{\mathrm{b}}$ \\
\hline
\end{tabular}

Keterangan :

IN-A : Tepung jagung+ Tanpa pati ACHMT-0 (100:0)

IN-B: Tepung jagung +Pati ACHMT-1 (75:25)

IN-C: Tepung jagung +Pati ACHMT-2 (50:50)

IN-D: Tepung jagung +Pati ACHMT-3 (25:75)

IN-E: Tanpa Tepung jagung +Pati ACHMT-4 (0:100)

IN-F: TanpaTepung jagung + pati alami $(0: 100)$ 
Kadar air yang terkandung didalam instant noodle memiliki peran sebagai upaya untuk memperpanjang masa simpan produk. Berdasarkan Hasil perhitungan statistik pada signifikan 5\% menunjukkan hasil yang tidak berbeda nyata dengan kisaran kadar air 9,884-9,890\%. Perbandingan formulasi instant noodle jagung tidak memberikan pengaruh pada kadar air instant noodle. Dengan pernyataan lain semakin banyaknya tepung jagung yang diberikan pada pembuatan instant noodle tidak memberikan pengaruh yang nyata pada kandungan air Instant noodle.

Tensile strength adalah salah satu sifat fisik instant noodle yang menunjukkan gaya maksimal yang dibutuhkan untuk memutuskan instant noodle. Sedangkan elongasi menunjukkan perubahan panjang instant noodle secara maksimal saat mendapatkan gaya tarik sampai putus yang dibandingkan dengan panjang awal. Pada Tabel 2. terlihat bahwa tensile strength dan elongasi Instant Noodle menunjukkan hasil berbeda nyata dimana instant noodle dari pati alami lebih rendah dibandingkan dengan instant noodle dari pati AC-HMT. Semakin banyak tepung jagung yang diberikan pada pembuatan instant noodle maka elongasi dan tensile strebght yang dihasilkan semakin menurun. Semakin banyak pati AC-HMT yang ditambahkan Nilai tensile strength instant noodle lebih tinggi. Ini menunjukkan besarnya gaya yang dibutuhkan untuk menarik instant noodle dibandingkan dengan instant noodle dari pati alami. Diduga hal ini disebabkan karena selama modifikasi AC-HMT kekompakan susunan molekul melalui ikatan hidrogen di dalam granula pati yang disebut fragmen meningkat, sehingga energi panas yang digunakan dalam proses gelatinisasi tidak mampu memecah ikatan hidrogen yang ada. Menurut Xu dan Seib (1993) adanya ACHMT akan menaikkan jumlah ikatan hydrogen granula pati sehingga mengakibatkan tingginya nilai tensile strength pada noodle dari pati ACHMT.

Nilai elongasi menunjukkan kemampuan instant noodle memanjang. Nilai elongasi yang lebih tinggi pada instant noodle dari pati AC-HMT disebabkan karena terbentuknya jaringan tiga dimensi yang lebih kuat pada pati yang telah mengalami modifikasi, sehingga memiliki ikatan yang lebih kuat (Whistler dan BeMiller, 1999). Dengan demikian instant noodle dari pati AC-HMT mengalami pemanjangan yang cukup besar saat dikenai gaya.Semakin besar tepung jagung yang ditambahkan akan menghasilkan tensile strenght dan elongasi yang lebih kecil atau menurun. Dari data formulasi instant noodle yang memiliki tensile strength, elongasi yang tinggi yaitu pada perlakuan AC-HMT $(25: 75)$

Pada Tabel 2 terlihat bahwa Instant Noodle hasil dari DMRT 5\% menunjukkan hasil yang berbeda nyata pada analisa kekuatan pengembangan dan kelarutan. Swelling Power/ kekuatan pengembangan menggambarkan kapasitas pengikatan air oleh pati. Semakin banyak tepung jagung yang ditambahkan maka kekuatan pengembangan instant noodle semakin berkurang. Menurut Tester dan Morrison (1990) swelling power dipengaruhi oleh kadungan amilosadan amilopektin yang ada pada granula pati. Granula pati akan mengembang terus-menerus ketika dipanaskan dalam air dan amilosa merupakan salah satu faktor penentu untuk tingginya tingkat swelling.

Kelarutan menunjukkan banyaknya kehilangan padatan dalam noodle akibat Pemasakan. Ikatan antar molekul pati pada noodle berperan penting terhadap kehilangan padatan selama pemasakan. Makin tinggi kemampuan pati membentuk gugus kristalin saat retrogradasi, kehilangan padatan akibat pemasakan makin rendah. Retrogradasi pati efektif untuk meningkatkan stabilitas formasi rantai molekul pati dalam granula sehingga menurunkan kehilangan padatan akibat pemasakan (Collado dan Corke, 1997). Makin banyak tepung jagung yang ditambahkan pada pembuatan instant noodle maka ikatan antar molekul pati makin 
berkurang, sehinggakehilangan padatan selama pemasakan makin besar.

\section{KESIMPULAN}

Kesimpulan pada hasil penelitian ini sebagai berikut :

1. Pati Jagung modifikasi AC-HMT dapat memperbaiki karakteristik fisik instant noodle jagung sehingga penggunaan pati jagung sebagai bahan dasar pengembangan produk terutama Instant noodle dapat lebih baik manfaatnya.

2. Semakin banyak pati jagung modifikasi yang ditambahkan pada pembuatan instant noodle menyebabkan karakteristi fisik instant noodle lebih baik yaitu elongasi, tensile strength dan swelling power semakin tinggi, kelarutan selama pemasakan semakin rendah yaitu pada formulasi perbandingan tepung jagung dan pati modifikasi $25: 75$

\section{DAFTAR PUSTAKA}

Anand, C. (2015). Modifikasi Pati Garutv Dengan Metode Debranching, Siklus Autoclaving-Cooling dan Heat Mouiture Treatment Untuk Meningkatkan Pati Resisten Tipe III (RS3). Fakultas Teknologi Pertanian Institut Pertanian Bogor. Bogor.

Budiyah. (2004). Pemanfaatan pati dan protein jagung (CGM) dalam pembuatan mi jagung instan. Skripsi. Departemen Ilmu dan Teknologi Pangan, Fakultas Teknologi Pertanian, Institut Pertanian Bogor, Bogor.

Collado, L.S. dan Corke, H. (1997). Properties of starch noodles of affected by sweet potato genotype. Cereal Chemistry, 74(2): 182-187.
Fadlillah, H. N. (2005). Verifikasi Formulasi Mi Jagung Instan dalam Rangka Penggandaan Skala. Skripsi. Departemen Ilmu dan Teknologi Pangan, Fakultas Teknologi Pertanian, Institut Pertanian Bogor, Bogor.

Juniawati. (2003). Optimasi proses pengolahan mi jagung instan berdasarkan kajian preferensi konsumen. Skripsi. Departemen Ilmu dan Teknologi Pangan,Fakultas Teknologi Pertanian, Institut Pertanian Bogor, Bogor.

Syamsir, E., Hariyadi, P., Fardiaz, D., Andar wulan, N. dan Kusnandar, F. (2012). Pengaruh proses heat - moisture treatment (HMT) terhadap karakteristik fisikokimia pati. Jurnal Teknology dan Industri Pangan, 28 (1): 100-106.

Tester, R.F., and Morrison, W.R., (1990). Swelling gelatinization of cereal starches I. effect of amylopectin, amylase and lipids. Cereal Chemistry, 67: 551-557

Whistler, R. dan BeMiller, J.N., (1999). Carbohydrate Chemistry for Food Scientiest. 2nd Edition. Eagen Press. St. Paul, Minnesota, USA

Xu, Y.X. and Seib, P.A., (1993). Structure tapioka pearls compared to starch noodles frommung beans. Cereal Chemistry, 70(4): 463-470

Zakiyah, (2010). Pengaruh suhu pemanasan awal dalam proses modifikasi pati garut dengan pemanasan dan pendinginan berulang terhadap Kadar pati Resisten Tipe 3 (RS3). Skripsi. Fakultas Teknologi Pertanian. IPB. 